\title{
Peranan Keputusan Investasi dan Pendanaan Pengaruhnya Terhadap Nilai Perusahaan Melalui Kinerja Keuangan
}

\author{
Ainun Jariah \\ STIE Widya Gama Lumajang \\ anjar040820@gmail.com
}

\begin{abstract}
Abstrak
Nilai perusahaan penting bagi perusahaan karena menggambarkan kesejahteraan pemilik. Pelaksanaan fungsi-fungsi manajemen keuangan yang hati-hati dan tepat akan berdampak pada nilai perusahaan. Keputusan keuangan dalam sudut pandang manajemen keuangan meliputi keputusan investasi, pendanaan, dan dividen. Penelitian ini bertujuan untuk mengetahui pengaruh keputusan investasi dan keputusan pendanaan secara langsung dan tidak langsung, secara parsial maupun simultan terhadap kinerja keuangan dan nilai perusahaan manufaktur di Indonesia. Jumlah sampel adalah 22 perusahaan manufaktur sector barang konsumsi yang rutin mempublikasikan laporan keuangan selama periode penelitian. Hasil penelitian menunjukkan bahwa secara parsial hanya keputusan investasi yang berpengaruh terhadap kinerja keuangan dan nilai perusahaan. Secara simultan berpengaruh secara signifikan terhadap kinerja keuangan dan nilai perusahaan. Diperoleh nilai koefisien korelasi berganda $(R)$ sebesar 0,953 dengan signifikansi 0,000 yang berarti terbukti terdapat hubungan dengan nilai perusahaan secara signifikan. Sedangkan nilai koefisien determinasi ( $R$ square) sebesar 0,908 atau 90,8\% berarti keputusan investasi dan keputusan pendanaan mampu menjelaskan pengaruhnya terhadap variabel nilai perusahaan secara bersama-sama sebesar $90,8 \%$ dan sisanya sebesar $9,2 \%$ dijelaskan oleh variabel lainnya.
\end{abstract}

Kata Kunci: Keputusan Pendanaan, Keputusan Investasi, Nilai Perusahaan, Kinerja Keuangan.

\begin{abstract}
Enterprise value is important to the company because it describes the welfare of the owner. Implementation of prudent and appropriate financial management functions will have an impact on company value. Financial decisions in the view of financial management include investment decisions, funding, and dividends. This study aims to determine the effect of investment decisions and funding decisions directly and indirectly, partially or simultaneously to the financial performance and value of manufacturing companies in Indonesia. The number of samples is 22 consumer goods manufacturing companies that routinely publish financial reports during the study period. The results showed that partially only investment decisions that affect the financial performance and corporate value. Simultaneously significant effect on financial performance and firm value. The value of multiple correlation coefficient $(R)$ is 0.953 with significance 0.000 , which means there is significant relationship with firm value. While the value of determination coefficient ( $R$ square) of 0.908 or $90.8 \%$ means investment decisions and financing decisions are able to explain the effect on corporate value variables together $90.8 \%$ and the rest of $9.2 \%$ explained by other variables.
\end{abstract}

Keyword: Funding Decision, Investment Decision, Value of Manufacturing, Performance of Manufacturing.

\section{PENDAHULUAN}

Perusahaan memiliki tujuan jangka pendek dan jangka panjang. Dalam jangka pendek perusahaan bertujuan memperoleh laba secara maksimal dengan menggunakan sumber daya yang ada. Sementara dalam jangka panjang tujuan utama perusahaan adalah memaksimalkan nilai perusahaan. Nilai perusahaan akan tergambar dari harga saham perusahaan yang bersangkutan. Nilai perusahaan penting bagi perusahaan karena menggambarkan kesejahteraan pemilik dan memaksimumkan nilai perusahaan merupkan salah satu tugas dari manajer keuangan.

Tujuan perusahaan tersebut dapat dicapai melalui pelaksanaan fungsi-fungsi manajemen keuangan dengan hati-hati dan tepat mengingat setiap keputusan keuangan yang diambil akan mempengaruhi keputusan keuangan yang lain sehingga berdampak pada nilai perusahaan (Fama \& French, 1998). Keputusan keuangan dalam sudut pandang manajemen keuangan meliputi keputusan investasi, pendanaan, dan dividen. Keputusan investasi, keputusan pendanaan, dan kebijakan dividen merupakan keputusan manajemen keuangan yang harus dipertimbangkan oleh manajer keuangan semua perusahaan dalam meningkatkan nilai perusahaan (Ningrum dan Febriana, 2006). Nilai perusahaan juga tercermin dari kinerja keuangan perusahaan (Safitri dan Lailatul, 2014). 
Keputusan investasi berkaitan dengan aktivitas pemilihan dan pengelolaan terhadap seluruh investasi yang dilakukan perusahaan. Sedangkan keputusan pendanaan berkaitan dengan aktivitas pemilihan dan penggunaan sumber dana perusahaan. Keputusan dividen berkaitan dengan aktivitas pengelolaan free cash flow perusahaan. Keseluruhan dari keputusan keuangan yang diambil tersebut harus dapat memaksimalkan kesejahteraan pemegang saham. Pemegang saham akan mempercayakan pengelolaan kepada pihak lain (pihak manajemen) dalam rangka meningkatkan nilai perusahaan.

Keputusan investasi sangat penting karena akan berpengaruh terhadap keberhasilan pencapaian tujuan perusahaan dan merupakan inti dari seluruh analisis keuangan (Brealy dan Myers, 2000). Nilai perusahaan yang dibentuk melalui nilai pasar saham, sangat dipengaruhi oleh peluang-peluang investasi. Keputusan investasi sangat dipengaruhi oleh ketersediaan dana perusahaan yang berasal dari sumber pendanaan. Keputusan pendanaan berkaitan dengan penentuan struktur modal yang tepat bagi perusahaan. Tujuan dari keputusan pendanaan adalah cara perusahaan menentukan sumber dana yang optimal untuk mendanai berbagai alternatif investasi, sehingga dapat memaksimalkan nilai perusahaan yang tercermin pada harga sahamnya (Septia, 2015).

Jensen (2001) menjelaskan bahwa untuk memaksimumkan nilai perusahaan dalam jangka panjang (tidak hanya nilai ekuitas, tetapi juga semua klaim keuangan seperti hutang, waran dan saham preferen) manajer dituntut untuk membuat keputusan yang memperhitungkan kepentingan semua stakeholders, sehingga manajer akan dinilai kinerjanya berdasarkan kemampuannya mencapai tujuan atau mampu mengimplementasikan strategi untuk mencapai tujuan ini.

Berdasarkan uraian tersebut diatas, maka peneliti ingin membuktikan peranan keputusan investasi dan pendanaan terhadap nilai perusahaan melalui kinerja keuangan Penelitian ini bertujuan untuk menganalisis pengaruh keputusan investasi, keputusan pendanaan terhadap nilai perusahaan melalui kinerja keuangan. Berdasarkan hal tersebut maka perumusan masalah dalam penelitian ini adalah sebagai berikut:

a. Apakah terdapat pengaruh keputusan investasi dan pendanaan yang signifikan secara parsial terhadap kinerja keuangan pada perusahaan manufaktur sektor barang konsumsi di Indonesia?

b. Apakah terdapat pengaruh keputusan investasi dan pendanaan yang signifikan secara simultan terhadap kinerja keuangan pada perusahaan manufaktur sektor barang konsumsi di Indonesia?

c. Apakah terdapat pengaruh keputusan investasi dan pendanaan yang signifikan secara parsial terhadap nilai perusahaan pada perusahaan manufaktur sektor barang konsumsi di Indonesia?

d. Apakah terdapat pengaruh keputusan investasi dan pendanaan yang signifikan secara simultan terhadap nilai perusahaan pada perusahaan manufaktur sektor barang konsumsi di Indonesia?

e. Apakah terdapat hubungan kinerja keuangan yang signifikan terhadap nilai perusahaan pada perusahaan manufaktur sektor barang konsumsi di Indonesia?

f. Apakah terdapat hubungan keputusan investasi dan pendanaan yang signifikan secara parsial terhadap nilai perusahaan melalui kinerja keuangan pada perusahaan manufaktur sektor barang konsumsi di Indonesia?

g. Apakah terdapat hubungan keputusan investasi dan pendanaan yang signifikan secara simultan terhadap nilai perusahaan melalui kinerja keuangan pada perusahaan manufaktur sektor barang konsumsi di Indonesia?

\section{KAJIAN PUSTAKA}

\section{a. Nilai Perusahaan}

Nilai perusahaan adalah Brealey et. al (2007:46) menyatakan bahwa nilai perusahaan mengikhtisarkan penilaian kolektif investor tentang seberapa baikkah keadaan suatu perusahaan, baik kinerja saat ini maupun proyeksi masa depannya. nilai perusahaan akan tercermin melalui harga saham perusahaan. Jika harga saham mengalami peningkatan maka nilai perusahaan juga akan mengalami peningkatan begitu juga sebaliknya.

\section{b. Kinerja Keuangan}

Kinerja keuangan menurut Irham Fahmi (2011:239) kinerja keuangan adalah suatu analisis yang dilakukan untuk melihat sejauh mana suatu perusahaan telah melaksanakan dengan menggunakan aturanaturan pelaksanaan keuangan secara baik dan benar. Seperti dengan membuat suatu laporan keuangan yang telah memenuhi standard dan ketentuan dalam SAK (standar akuntansi keuangan) atau GAAP (General Acepted Accounting Principle), dan lainnya.

\section{c. Keputusan Investasi}

Sartono (2001:6) mengemukakan bahwa keputusan investasi menyangkut tentang keputusan alokasi dana baik dana yang berasal dari dalam perusahaan maupun dana yang berasal dari luar perusahaan pada berbagai bentuk investasi.

\section{d. Keputusan Pendanaan}


Keown et al., (2010:121), mengemukakan bahwa kebijakan hutang adalah kebijakan yang dilakukan perusahaan untuk mendanai operasinya dengan menggunakan hutang keuangan atau yang biasa disebut dengan finansial leverage atau leverage keuangan. Leverage keuangan adalah praktek pendanaan sebagian aktiva perusahaan dengan sekuritas yang menanggung beban pengembalian tetap dengan harapan bisa meningkatkan pengembalian akhir bagi pemegang saham.

Beberapa penelitian terdahulu yang relevan berisi tentang analisis terhadap penelitian yang telah dilakukan sebelumnya antara lain:

a. Penelitian yang dilakukan oleh Jubaedah and Jenji Gunaedi Argo (2012) dengan judul The Influence Of Investment Decision, Capital Decision And Financial Performance On The Company Values In Manufacture Company Registered In Indonesian Stock Market. Variabel penelitian keputusan investasi, keputusan pendanaan, kinerja keuangan, dan nilai perusahaan, metode penelitian menggunakan SEM. Hasil penelitian menunjukkan bahwa Keputusan investasi, keputusan pendanaan berpengaruh signifikan terhadap kinerja keuangan, keputusan investasi, keputusan pendanaan, dan kinerja keuangan berpengaruh signifikan terhadap nilai perusahaan.

b. Penelitian yang dilakukan Cindy Leony Santoso (2017) dengan judul "Hubungan Keputusan Investasi, Keputusan Pendanaan, Kebijakan Dividen, Tingkat Inflasi dan Suku Bunga Dengan Nilai Perusahaan”. Dengan menggunakan analisis tabulasi silang (crosstabs), menunjukkan bahwa keputusan investasi memiliki hubungan yang lemah dan negatif dengan nilai perusahaan, keputusan pendanaan memiliki hubungan yang sangat lemah dan positif dengan nilai perusahaan, dan kebijakan dividen memiliki hubungan yang sangat lemah dan negatif dengan nilai perusahaan.

c. Penelitian yang dilakukan Alfredo Mahendra DJ (2011) dengan judul "Pengaruh Kinerja Keuangan terhadap nilai perusahaan (Kebijakan Dividen sebagai Variabel Moderating) Pada Perusahaan Manufaktur Di Bursa Efek Indonesia". Menggunakan analisis regresi, hasil penelitian menunjukkan kebijakan dividen tidak mampu secara signifikan memoderasi pengaruh likuiditas terhadap nilai perusahaan, kebijakan dividen tidak mampu secara signifikan memoderasi pengaruh profitabilitas terhadap nilai perusahaan.

d. Penelitian yang dilakukan Lais Khafa (2015) dengan judul "Pengaruh CSR, Ukuran Perusahaan, Leverage, dan Keputusan Investasi Pada Kinerja Keuangan Perusahaan dan Nilai Perusahaan (Studi empiris pada Perusahaan Manufaktur yang Terdaftar Di Bursa Efek Indonesia Tahun 2012 - 2013). Dengan menggunakan analisis regresi berganda, hasil penelitian menunjukkan bahwa CSR berpengaruh positif terhadap kinerja perusahaan, ukuran perusahaan berpengaruh negatif terhadap kinerja perusahaan, leverage berpengaruh negatif terhadap kinerja perusahaan, keputusan investasi berpengaruh positif terhadap kinerja perusahaan, dan kinerja berpengaruh positif terhadap nilai perusahaan.

e. Penelitian yang dilakukan Rury Setiani (2014) dengan judul Pengaruh Keputusan Investasi, Keputusan Pendanaan, dan Tingkat Suku Bunga Terhadap Nilai Perusahaan pada Perusahaan Otomotif yang Terdaftar di Bursa Efek Indonesia. Dengan menggunakan model regresi panel, hasil penelitian menunjukkan bahwa keputusan investasi berpengaruh tidak signifikan dan negatif terhadap nilai perusahaan, keputusan pendanaan berpengaruh signifikan dan positif terhadap nilai perusahaan, dan tingkat suku bunga berpengaruh signifikan dan negatif terhadap nilai perusahaan.

f. Penelitian yang dilakukan oleh Andina dan Nadia Putri (2015) dengan judul Pengaruh Keputusan Investasi, Keputusan Pendanaan, dan Kebijakan Dividen Terhadap Nilai Perusahaan, dengan metode analisis regresi berganda. Hasil penelitian menunjukkan bahwa keputusan investasi berpengaruh secara positif namun tidak signifikan terhadap nilai perusahaan, keputusan pendanaan berpengaruh secara positif dan signifikan terhadap nilai perusahaan, dan kebijakan dividen berpengaruh secara positif dan signifikan terhadap nilai perusahaan.

g. Penelitian yang dilakukan oleh Arie Afzal dan abdul Rahman (2012) dengan judul Pengaruh Keputusan Investasi, Keputusan Pendanaan, dan Kebijakan Dividen Terhadap Nilai Perusahaan, dengan menggunakan ordinary least square (OLS). Hasil penelitian menunjukkan bahwa keputusan investasi dan keputusan pendanaan berpengaruh positif dan signifikan terhadap nilai perusahaan, sedangkan kebijakan dividen memiliki pengaruh yang negatif dan tidak signifikan terhadap nilai perusahaan.

\section{METODE PENELITIAN \\ Jenis Penelitian}

Penelitian ini termasuk jenis penelitian survei (survey research) yaitu penelitian yang tidak melakukan perubahan atau tidak ada perlakuan khusus terhadap variabel-variabel yang diteliti (non experimental). Tujuan penelitian ini bersifat eksplanatori (explanatory research) dan prediksi dimana penelitian eksplanatori merupakan jenis penelitian yang menjelaskan hubungan kausal antara satu variabel dengan variabel lainnya melalui pengujian hipotesis. Berdasarkan sifatnya, penelitian ini bersifat eksploratif karena pengujian lebih lanjut atas suatu penelitian. 


\section{Obyek Penelitian}

Obyek penelitian ini adalah keputusan investasi, keputusan pendanaan, kebijakan dividen, kinerja keuangan, dan nilai perusahaan. Penelitian ini dilakukan terhadap perusahaan manufaktur sektor barang konsumsi yang terdaftar di Bursa Efek Indonesia periode 2014 - 2016. Alasan dipilihnya perusahaan manufaktur yang terdaftar di Bursa Efek Indonesia sebagai lokasi penelitian karena perusahaan tersebut adalah perusahaan terbuka sehingga peneliti lebih mudah untuk memperoleh data keuangan yang diperlukan.

\section{Populasi dan Teknik Pengambilan Sampel}

Populasi dalam penelitian ini adalah perusahaan manufaktur yang terdaftar di Bursa Efek Indonesia, periode 2014 - 2016, yang keseluruhan berjumlah 72. Pengambilan sampel dilakukan dengan metode purposive sampling. Kriteria perusahaan manufaktur yang dapat dijadikan sampel penelitian ini adalah:

a. Perusahaan manufaktur yang listed di Bursa Efek Indonesia pada periode penelitian.

b. Perusahaan manufaktur yang sudah berdiri dan terdaftar dalam Bursa Efek Indonesia minimal sejak tahun 2012.

c. Perusahaan yang pada periode penelitian tidak melaksanakan akuisisi dan merger.

d. Laporan keuangan perusahaan menggunakan satuan uang yang sama selama periode penelitian.

\section{Teknik Analisis Data}

Teknik analisis data dalam penelitian ini akan dilakukan dengan menggunakan model analisis jalur dengan aplikasi SPSS. Dengan mempertimbangkan pula uji asumsi klasik/pengujian asumsi dasar untuk memenuhi kaidah-kaidah dalam model regresi yang telah dirancang dalam penelitian ini. Untuk pengujian hipotesis menggunakan analisis dua jalur dengan tahap-tahap penyelesaian analisis sebagai berikut:

(a) Menentukan model diagram jalur berdasarkan paradigma hubungan variabel.

(b) Menentukan hipotesis penelitian.

(c) Pengolahan data dengan SPSS untuk substruktur 1.

(d) Pengolahan data dengan SPSS untuk substruktur 2.

(e) Melakukan analisis output regresi.

(f) Menguji ketepatan model yang dihasilkan.

(g) Menentukan model persamaan analisis regresi untuk dua jalur.

\section{HASIL DAN PEMBAHASAN}

\section{Hasil Penelitian}

Perusahaan manufaktur yang dijadikan populasi adalah perusahaan manufaktur sektor industri barang konsumsi yang terdaftar di Bursa Efek Indonesia sampai dengan tahun 2016. Setelah dilakukan pengambilan sampel dengan menggunakan kriteria tertentu, maka dari 37 perusahaan hanya 22 perusahaan yang bisa dijadikan sampel penelitian.

Tabel 1. Perusahaan Manufaktur yang Menjadi Sampel Penelitian

\begin{tabular}{|c|l|l|c|}
\hline NO & KODE & \multicolumn{1}{|c|}{ NAMA PERUSAHAAN } & $\begin{array}{c}\text { LAP. KEUANGAN YANG } \\
\text { DIGUNAKAN }\end{array}$ \\
\hline 1 & ALTO & PT. TRI BANYAN TIRTA, Tbk. & 31 DESEMBER 2014-2016 \\
2 & CEKA & PT. WILMAR CAHAYA INDONESIA, Tbk. & 31 DESEMBER 2014-2016 \\
3 & DLTA & PT. DELTA JAKARTA, Tbk. & 31 DESEMBER 2014-2016 \\
4 & ICBP & PT. INDOFOOD CBP SUKSES MAKMUR, Tbk. & 31 DESEMBER 2014-2016 \\
5 & INDF & PT. INDOFOOD SUKSES MAKMUR, Tbk. & 31 DESEMBER 2014-2016 \\
6 & GGRM & PT. GUDANG GARAM, Tbk. & 31 DESEMBER 2014-2016 \\
7 & HMSP & PT. HANJAYA MANDALA SAMPOERNA, Tbk. & 31 DESEMBER 2014-2016 \\
8 & WIIM & PT. WISMILAK INTI MAKMUR, Tbk. & 31 DESEMBER 2014-2016 \\
9 & DVLA & PT. DARYA VARIA LABORATORIA, Tbk. & 31 DESEMBER 2014-2016 \\
10 & INAF & PT. INDOFARMA, Tbk. & 31 DESEMBER 2014-2016 \\
11 & KLBF & PT. KALBE FARMA, Tbk. & 31 DESEMBER 2014-2016 \\
12 & MERK & PT. MERCK, Tbk. & 31 DESEMBER 2014-2016 \\
13 & PYFA & PT. PYRIDAM FARMA, Tbk. & 31 DESEMBER 2014-2016 \\
14 & SQBB & PT.TAISHO PHARMACEUTICAL INDONESIA, Tbk. & 31 DESEMBER 2014-2016 \\
15 & TSPC & PT. TEMPO SCAN PASIFIC, Tbk. & 31 DESEMBER 2014-2016 \\
16 & ADES & PT. AKASHA WIRA INTERNAL, Tbk. & 31 DESEMBER 2014-2016 \\
17 & MBTO & PT. MARTINA BERTO, Tbk. & 31 DESEMBER 2014-2016 \\
18 & MRAT & PT. MUSTIIKA RATU, Tbk. & 31 DESEMBER 2014-2016 \\
19 & TCID & PT. MANDOM INDONESIA, Tbk. & 31 DESEMBER 2014-2016 \\
20 & KICI & PT. KEDAUNG INDAG CAN, Tbk. & 31 DESEMBER 2014-2016 \\
21 & LMPI & PT. LANGGENG MAKMUR INDUSTRY, Tbk. & 31 DESEMBER 2014-2016 \\
22 & CINT & PT. CHITOSE INTERNASIONAL, Tbk. & 31 DESEMBER 2014-2016 \\
\hline
\end{tabular}

Sumber data: www.sahamok.com/perusahaan-manufaktur-di-bei/manufaktur

Berdasarkan sampel yang telah dipilih, berikut disajikan hasil perhitungan masing-masing variabel pada 22 perusahaan manufaktur sektor barang konsumsi. 
Tabel 2. Hasil Perhitungan Keputusan Investasi

\begin{tabular}{|c|c|c|c|c|}
\hline NO & $\begin{array}{c}\text { KODE } \\
\text { PERUSAHAAN }\end{array}$ & $\mathbf{2 0 1 4}$ & $\mathbf{2 0 1 5}$ \\
\hline 1 & ALTO & 1,19 & 1,17 & 1,21 \\
2 & CEKA & 0,93 & 0,84 & 3,50 \\
3 & DLTA & $0,24,19$ & 2,09 \\
4 & ICBP & 3,46 & 3,34 & 1,31 \\
5 & INDF & 1,21 & 1,03 & 2,32 \\
6 & GGRM & 2,44 & 0,62 \\
7 & HMSP & 11,13 & 1,07 & 0,95 \\
8 & WIIM & 1,34 & 0,97 & 1,58 \\
9 & DVLA & 1,75 & 1,35 & 4,08 \\
10 & INAF & 1,36 & 0,95 & 0,49 \\
11 & KLBF & 7,11 & 0,72 & 1,01 \\
12 & MERK & 5,23 & 0,74 & 0,46 \\
13 & PYFA & 0,86 & 0,45 & 1,64 \\
14 & SQBB & 0,41 & 1,56 & 1,27 \\
15 & TSPC & 2,57 & 0,79 & 0,66 \\
16 & ADES & 0,83 & 0,56 & 0,42 \\
17 & MBTO & 0,61 & 0,42 & 1,33 \\
18 & MRAT & 0,53 & 1,77 & 0,48 \\
19 & TCID & 2,21 & 0,56 & 0,66 \\
20 & KICI & 0,57 & 0,64 & 0,97 \\
21 & LMPI & 0,72 & 1,06 & 2017 \\
\hline
\end{tabular}

Sumber data: Data Laporan Keuangan pada Bursa Efek Indonesia diolah, 2017

Tabel 3. Hasil Perhitungan Keputusan Pendanaan

\begin{tabular}{|c|c|c|c|c|}
\hline NO & $\begin{array}{c}\text { KODE } \\
\text { PERUSAHAAN }\end{array}$ & $\mathbf{2 0 1 4}$ & $\mathbf{2 0 1 5}$ \\
\hline 1 & ALTO & 0,57 & 0,57 & 0,59 \\
2 & CEKA & 0,58 & 0,57 & 0,15 \\
3 & DLTA & 0,23 & 0,36 \\
4 & ICBP & 0,18 & 0,47 \\
5 & INDF & 0,40 & 0,53 & 0,37 \\
6 & GGRM & 0,52 & 0,40 & 0,20 \\
7 & HMSP & 0,43 & 0,16 & 0,24 \\
8 & WIIM & 0,52 & 0,30 & 0,58 \\
9 & DVLA & 0,36 & 0,29 & 0,18 \\
10 & INAF & 0,22 & 0,22 \\
11 & KLBF & 0,53 & 0,20 & 0,37 \\
12 & MERK & 0,21 & 0,26 & 0,26 \\
13 & PYFA & 0,23 & 0,37 & 0,30 \\
14 & SQBB & 0,44 & 0,31 & 0,50 \\
15 & TSPC & 0,20 & 0,50 & 0,24 \\
16 & ADES & 0,26 & 0,33 & 0,24 \\
17 & MBTO & 0,41 & 0,24 & 0,18 \\
18 & MRAT & 0,27 & 0,18 & 0,36 \\
19 & TCID & 0,23 & 0,30 & 0,50 \\
20 & KICI & 0,31 & 0,49 & 0,18 \\
21 & LMPI & 0,19 & 0,18 & 2017 \\
\hline
\end{tabular}

Sumber data: Data Laporan Keuangan pada Bursa Efek Indonesia diolah, 2017

Tabel 4. Hasil Perhitungan Kinerja Keuangan

\begin{tabular}{|c|c|c|c|c|}
\hline NO & KODE & $\mathbf{2 0 1 4}$ & $\mathbf{2 0 1 5}$ & $\mathbf{2 0 1 6}$ \\
\hline 1 & PERUSAHAAN & $-0,05$ & $-0,11$ & $-0,12$ \\
2 & ALTO & 0,28 & 0,72 & 1,68 \\
3 & CEKA & 17,99 & 11,99 & 6,23 \\
4 & DLTA & 4,34 & 5,01 & 5,53 \\
5 & ICBP & 5,01 & 3,68 & 6,94 \\
6 & INDF & 5,61 & 6,71 & 27,43 \\
7 & GGRM & 23,23 & 22,27 & 0,51 \\
8 & HMSP & 0,62 & 0,54 \\
9 & WIIM & 0,53 & 0,39 & $-0,06$ \\
10 & DVLA & 0,29 & 5,02 & 5,02 \\
11 & INAF & 0,00 & 4,39 & 0,10 \\
12 & KLBF & 4,52 & 0,36 & 17,82 \\
13 & MERK & 8,10 & 0,06 & 2,42 \\
14 & PYFA & 0,05 & 16,21 & 0,09 \\
15 & SQBB & 17,78 & 2,35 & 0,08 \\
16 & TSPC & 2,60 & 0,06 & $-0,10$ \\
17 & ADES & 0,05 & $-0,13$ & 0,02 \\
18 & MBTO & 0,03 & & \\
\hline
\end{tabular}




\begin{tabular}{|l|l|l|l|l|}
\hline 19 & TCID & 1,73 & 5,42 & 1,61 \\
20 & KICI & 0,07 & $-0,19$ & 0,01 \\
21 & LMPI & 0,00 & 0,01 & 0,01 \\
22 & CINT & 0,25 & 0,29 & 0,21 \\
\hline
\end{tabular}

Sumber data: Data Laporan Keuangan pada Bursa Efek Indonesia diolah 2017

Tabel 5. Hasil Perhitungan Nilai Perusahaan

\begin{tabular}{|c|c|c|c|c|}
\hline NO & KODE & $\mathbf{2 0 1 4}$ & $\mathbf{2 0 1 5}$ & $\mathbf{2 0 1 6}$ \\
\hline 1 & PERUSAHAAN & 1,44 & 1,40 & 1,50 \\
2 & ALTO & 0,83 & 0,63 & 0,90 \\
3 & CEKA & 0,01 & 4,90 & 3,95 \\
4 & DLTA & 5,08 & 4,79 & 1,50 \\
5 & ICBP & 1,44 & 1,05 & 3,11 \\
6 & INDF & 3,51 & 2,78 & 0,52 \\
7 & GGRM & 13,66 & 0,93 \\
8 & HMSP & 1,29 & 0,96 & 25,82 \\
9 & WIIM & 1,54 & 5,70 \\
10 & DVLA & 1,97 & 0,35 \\
11 & INAF & 0,75 & 0,88 & 1,01 \\
12 & KLBF & 8,74 & 0,66 & 1,27 \\
13 & MERK & 6,47 & 0,32 & 1,53 \\
14 & PYFA & 0,75 & 0,59 & 0,45 \\
15 & SQBB & 0,26 & 1,27 & 0,24 \\
16 & TSPC & 3,12 & 0,58 & 1,41 \\
17 & ADES & 0,70 & 0,34 & 0,19 \\
18 & MBTO & 0,47 & 0,24 & 0,33 \\
19 & MRAT & 0,39 & 1,93 & 0,97 \\
20 & TCID & 0,75 & 0,37 & 2017 \\
21 & KICI & 0,47 & 0,28 & \\
22 & LMPI & 0,44 & 1,07 & \\
\hline
\end{tabular}

Sumber data: Data Laporan Keuangan pada Bursa Efek Indonesia diolah 2017

\section{Hasil Pengujian Asumsi Dasar}

Hasil Uji Normalitas

Pengujian normalitas dilakukan terhadap residual regresi. Pengujian dilakukan dengan menggunakan grafik P-P Plot. Hasil pengujian normalitas data menunjukkan adanya pola grafik yang normal dimana titiktitik berada tidak jauh dari garis diagonal, hal ini berarti bahwa model regresi tersebut sudah berdistribusi normal.

\section{Hasil Uji Multikolinieritas}

Suatu variabel menunjukkan gejala multikolinieritas bisa dilihat dari nilai VIF (Variance Inflation Factor) yang tinggi pada variabel-variabel bebas suatu model regresi. Nilai VIF yang lebih besar dari 10 menunjukkan adanya gejala multikolinieritas dalam model regresi. Hasil pengujian menunjukkan bahwa semua variabel yang digunakan sebagai prediktor model regresi menunjukkan nilai VIF yang cukup kecil, dimana semuanya berada di bawah 10 dan nilai tollerance lebih dari 0,1. Hal ini berarti bahwa variabel bebas yang digunakan dalam penelitian tidak menunjukkan adanya gejala multikolinieritas.

\section{Hasil Uji Autokorelasi}

Penggunaan uji autokorelasi adalah untuk melihat apakah ada hubungan linier antara error serangkaian observasi yang diurutkan menurut waktu (data time series). Berdasarkan hasil uji, maka dapat disimpulkan model regresi yang dihasilkan pada penelitian ini bebas dari autokorelasi.

\section{Hasil Uji Heteroskedastisitas}

Pengujian heteroskedastisitas dilakukan dengan menggunakan Scatter Plot. Jika tidak terdapat variabel yang signifikan maka dapat disimpulkan tidak adanya masalah heteroskedastisitas. Hasil pengujian heteroskedastisitas menunjukkan tidak terdapat pola yang jelas dari titik-titik tersebut. Hal ini menunjukkan bahwa model regresi tidak memiliki gejala adanya heteroskedastisitas, yang berarti bahwa tidak ada gangguan yang berarti dalam model regresi.

\section{Hasil Pengujian Hipotesis \\ Pengujian Hipotesis 1}

Pengujian hipotesis secara parsial atau individu untuk masing-masing variabel melalui pengujian model substruktur kedua sebagai berikut:

a) Pengaruh keputusan investasi $\left(X_{1}\right)$ terhadap kinerja keuangan $\left(Y_{1}\right)$

Diperoleh nilai t hitung sebesar 3,216 dengan tingkat signifikan 0,002 berarti

$(3,216)>t$ tabel $(1,998)$ dan sig $(0,002)<\alpha(0,05)$ maka $H_{a}$ diterima dan $H_{0}$ ditolak, sehingga dapat disimpulkan bahwa keputusan investasi $\left(\mathrm{X}_{1}\right)$ berpengaruh signifikan terhadap kinerja keuangan $\left(\mathrm{Y}_{1}\right)$. 
b) Pengaruh keputusan pendanaan $\left(X_{2}\right)$ terhadap kinerja keuangan $\left(Y_{1}\right)$

Diperoleh nilai t hitung sebesar $-0,939$ dengan tingkat signifikan 0,351 berarti

$0,939)<t$ tabel $(1,998)$ dan sig $(0,351)>\alpha(0,05)$ maka $\mathrm{H}_{\mathrm{a}}$ ditolak dan $\mathrm{H}_{0}$ diterima, sehingga dapat disimpulkan bahwa keputusan pendanaan $\left(\mathrm{X}_{2}\right)$ tidak berpengaruh signifikan terhadap kinerja keuangan (Y1).

\section{Pengujian Hipotesis 2}

Dari hasil pengujian diperoleh nilai $F$ hitung sebesar 5,794 dengan tingkat signifikan 0,005 berarti $F$ hitung $(5,794)>F$ tabel $(3,14)$ dan sig $(0,005)<\alpha(0,05)$ maka $H_{a}$ diterima dan $H_{0}$ ditolak, sehingga dapat disimpulkan bahwa terdapat pengaruh keputusan investasi dan keputusan pendanaan yang signifikan secara simultan terhadap kinerja keuangan pada perusahaan manufaktur sektor barang konsumsi di Indonesia.

\section{Pengujian Hipotesis 3}

Pengujian hipotesis secara parsial atau individu untuk masing-masing variabel melalui pengujian model substruktur kedua sebagai berikut:

\section{a. Pengaruh keputusan investasi $\left(X_{1}\right)$ terhadap nilai perusahaan $\left(Y_{2}\right)$}

Diperoleh nilai $t$ hitung sebesar 24,986 dengan tingkat signifikan 0,000 berarti $t_{\text {hitung }}(24,986)>t_{\text {tabel }}$ $(1,998)$ dengan sig $(0,000)<\alpha(0,05)$ maka $\mathrm{H}_{a}$ diterima dan $\mathrm{H}_{0}$ ditolak, sehingga dapat disimpulkan bahwa keputusan investasi $\left(\mathrm{X}_{1}\right)$ berpengaruh signifikan terhadap nilai perusahaan $\left(\mathrm{Y}_{2}\right)$.

\section{b. Pengaruh keputusan pendanaan $\left(X_{2}\right)$ terhadap nilai perusahaan $\left(Y_{2}\right)$}

Diperoleh nilai $t$ hitung sebesar 0,708 dengan tingkat signifikan 0,482 berarti $t_{\text {hitung }}(0,708)<t_{\text {tabel }}(1,998)$ dengan sig $(0,482)>a(0,05)$ maka $\mathrm{H}_{a}$ ditolak dan $\mathrm{H}_{0}$ diterima, sehingga dapat disimpulkan bahwa keputusan pendanaan $\left(\mathrm{X}_{2}\right)$ tidak berpengaruh signifikan terhadap nilai perusahaan $\left(\mathrm{Y}_{2}\right)$.

\section{Pengujian Hipotesis 4}

Dari hasil pengujian diperoleh nilai $F_{\text {hitung }}$ sebesar 312,378 dengan tingkat signifikan 0,000 berarti $F_{\text {hitung }}$ $(312,378)>F_{\text {tabel }}(3,14)$ dan sig $(0,000)<\alpha(0,05)$ maka $H_{a}$ diterima dan $H_{0}$ ditolak, sehingga dapat disimpulkan terdapat pengaruh keputusan investasi dan keputusan pendanaan yang signifikan secara simultan terhadap nilai perusahaan pada perusahaan manufaktur sektor barang konsumsi di Indonesia.

\section{Pengujian Hipotesis 5}

Diperoleh nilai t hitung sebesar 2,684 dengan tingkat signifikan 0,009 berarti $t_{\text {hitung }}(2,684)>t_{\text {tabel }}(1,998)$ dan sig $(0,009)<\alpha(0,05)$ maka $\mathrm{H}_{\mathrm{a}}$ diterima dan $\mathrm{H}_{0}$ ditolak, sehingga disimpulkan bahwa kinerja keuangan $\left(Y_{1}\right)$ memiliki hubungan yang signifikan terhadap nilai perusahaan $\left(Y_{2}\right)$.

\section{Pengujian Hipotesis 6}

Dari hasil pengujian diketahui korelasi atau hubungan antara keputusan investasi dan keputusan pendanaan secara parsial terhadap nilai perusahaan melalui kinerja keuangan pada perusahaan manufaktur sektor barang konsumsi di Indonesia sebagai berikut:

a) Nilai korelasi antara keputusan investasi (X1) dengan nilai perusahaan (Y2) sebesar 0,953 dengan tingkat signifikansi 0,000 berarti terdapat hubungan yang signifikan.

b) Nilai korelasi antara keputusan pendanaan (X2) dengan nilai perusahaan (Y2) sebesar -0,025 dengan tingkat signifikansi 0,420 berarti terdapat hubungan yang tidak signifikan.

\section{Pengujian Hipotesis 7}

Berdasarkan output pengujian keputusan investasi dan keputusan pendanaan terhadap nilai perusahaan melalui kinerja keuangan diperoleh dari :

\section{Hubungan Keputusan Investasi Dan Keputusan Pendanaan Secara Simultan Terhadap Kinerja} Keuangan.

Nilai koefisien korelasi berganda $(R)$ sebesar 0,394 dengan signifikansi 0,005 yang berarti terbukti terdapat hubungan dengan kriteria yang cukup positif dan signifikan. Sedangkan nilai koefisien determinasi ( $R$ square) sebesar 0,155 atau $15,5 \%$ yang artinya variabel keputusan investasi dan keputusan pendanaan mampu menjelaskan pengaruhnya terhadap perubahan variabel kinerja keuangan pada perusahaan manufaktur sektor barang konsumsi di Indonesia hanya sebesar $15,5 \%$ sedangkan sisanya sebesar $84,5 \%$ dijelaskan oleh variabel lainnya.

Hubungan Keputusan Investasi Dan Keputusan Pendanaan Secara Simultan Terhadap Nilai

\section{Perusahaan.}

Nilai koefisien korelasi berganda $(R)$ sebesar 0,953 dengan signifikansi 0,000 yang berarti terbukti terdapat hubungan dengan kriteria yang sangat kuat positif dan signifikan. Sedangkan nilai koefisien determinasi ( $R$ square) sebesar 0,908 atau $90,8 \%$ yang artinya variabel keputusan investasi dan keputusan pendanaan mampu menjelaskan pengaruhnya terhadap perubahan variabel nilai perusahaan manufaktur sektor barang konsumsi di Indonesia secara bersama-sama sebesar $90,8 \%$ dan sisanya 
$9,2 \%$ dijelaskan oleh variabel lainnya.

\section{PEMBAHASAN}

\section{Pembahasan Hasil Pengujian Hipotesis Pertama}

Pembahasan ini berkaitan dengan hasil pengujian terhadap hipotesis pertama yang menyatakan bahwa terdapat pengaruh keputusan investasi dan keputusan pendanaan yang signifikan secara parsial terhadap kinerja keuangan pada perusahaan manufaktur sektor barang konsumsi di Indonesia. Hasil penelitian menunjukkan bahwa keputusan investasi berpengaruh signifikan terhadap kinerja keuangan, sedangkan keputusan pendanaan tidak berpengaruh signifikan terhadap kinerja keuangan. Sampel penelitian adalah perusahaan manufaktur sektor barang konsumsi Berdasarkan uraian tersebut dan kondisi kenyataan untuk semua perusahaan yang dijadikan sampel dalam penelitian ini, maka tampak bahwa sebagian besar dana perusahaan diperuntukkan atau diinvestasikan pada akun persediaan, kenapa harus pada akun persediaan karena untuk menunjang kegitan penjualan perusahaan. Persediaan yang banyak menyebabkan penjualan lancar dan mampu memenuhi permintaan konsumen ataupun pelanggan. Selain itu dana juga banyak diinvestasikan untuk piutang, karena pada saat sekarang ini banyak pelanggan ataupun konsumen menyenangi penjualan secara kredit. Tidak hanya itu ternyata dana juga diinvestasikan pada akun kas, karena kas adalah aset paling likuid yang bisa memenuhi segala hal termasuk kegiatan penjualan. Kas yang banyak maka perusahaan bisa terhindar dari risiko tidak mampu memenuhi kewajiban terutama jangka pendek. Berdasarkan hasil pengolahan data penelitian didapatkan bahwa rasio hutang memiliki nilai kurang dari 1 (satu), menurut kententuan seharusnya nilai dari rasio hutang yang kurang dari satu menunjukkan bahwa perusahaan dalam kondisi aman, baik bagi perusahaan itu sendiri, kreditur maupun investor. Aman dalam artian aktiva perusahaan lebih banyak didanai dengan menggunakan modal sendiri dibandingkan dengan hutang. Bagi investor jika tidak terlalu banyak hutang, maka perusahaan terhindar dari risiko tidak mampu melunasi kewajibannya baik jangka panjang maupun jangka pendek. Tetapi hal itu semua tidak mampu mempengaruhi nilai perusahaan yang dilambangkan pada harga saham, karena investor lebih memperhatikan pada bagaimana penggunaan atau diinvestasikan pada apa dana tersebut bukan dari mana dana tersebut didapatkan.

\section{Pembahasan Hasil Pengujian Hipotesis Kedua}

Pembahasan ini berkaitan dengan hasil pengujian terhadap hipotesis kedua yang menyatakan bahwa terdapat pengaruh keputusan investasi dan keputusan pendanaan yang signifikan secara simultan terhadap kinerja keuangan pada perusahaan manufaktur sektor barang konsumsi di Indonesia. Hasil penelitian menunjukkan bahwa keputusan investasi dan keputusan pendanaan secara simultan berpengaruh signifikan terhadap kinerja keuangan. Nilai perusahaan yang dibentuk melalui nilai pasar saham, sangat dipengaruhi oleh peluang-peluang investasi. Keputusan investasi sangat dipengaruhi oleh ketersediaan dana perusahaan yang berasal dari sumber pendanaan. Keputusan pendanaan berkaitan dengan penentuan struktur modal yang tepat bagi perusahaan. Keputusan pendanaan menunjukkan dari mana sumber atau asal dana yang digunakan untuk membiayai atau mendanai atau membelanjai aset perusahaan. Sedangkan keputusan investasi adalah terkait dengan penggunaan atau penempatan dana dengan tujuan untuk memelihara atau meningkatkan nilai serta mengharapkan hasil atau return positif atas kegiatan tersebut. Jadi keputusan pendanaan dan keputusan investasi sangat berpengaruh sekali terhadap kinerja keuangan, karena perusahaan mampu memanage keputusan pendanaan dan investasi yang baik maka akan mampu meningkatkan kinerja keuangan, sedangkan jika sebaliknya perusahaan kurang mampu memanage antara keputusan pendanaan dan investasi menurun maka kinerja keuangan akan menurun. Investor melihat pengaruh keputusan investasi dan pendanaan secara bersama-sama.

\section{Pembahasan Hasil Pengujian Hipotesis Ketiga}

Pembahasan ini berkaitan dengan hasil pengujian terhadap hipotesis ketiga yang menyatakan bahwa terdapat pengaruh keputusan investasi dan keputusan pendanaan yang signifikan secara parsial terhadap nilai perusahaan pada perusahaan manufaktur sektor barang konsumsi di Indonesia. Hasil penelitian menunjukkan bahwa keputusan investasi berpengaruh signifikan terhadap nilai perusahaan, sedangkan keputusan pendanaan tidak berpengaruh signifikan terhadap nilai perusahaan. "signalling theory menyatakan pengeluaran investasi memberikan sinyal positif tentang pertumbuhan perusahaan dimasa yang akan datang, sehingga meningkatkan harga saham sebagai indikator nilai perusahaan. Keputusan investasi akan bercermin pada sisi aktiva perusahaan. Dengan demikian akan mempengaruhi kekayaan perusahaan, yaitu perbandingan antara aktiva lancar dengan aktiva tetap. Sebaliknya keputusan pendanaan dan kebijakan deviden akan tercermin pada sisi pasiva perusahaan. Apabila kita hanya memperhatikan dana yang ditanam dalam jangka waktu yang lama, maka perbandingan tersebut sebagai struktur modal. Apabila diperhatikan baik dana jangka pendek maupun dana jangka panjang, perbandingan tersebut sebagi struktur finansial. Perusahaan manufaktur sektor barang konsumsi yang dijadikan sampel dalam penelitian ini hampir semuanya memiliki komposisi aset lancar yang cukup tinggi terutama pada akun persediaan, piutang, dan kas. Ketiga akun tersebut adalah komponen modal kerja kotor (gross working capital). Besarnya modal kerja 
harus tetap dijaga agar mampu memenuhi nilai penjualan yang diinginkan yakni yang semakin lama semakin meningkat. Besarnya modal kerja harus tetap terjaga aman agar perusahaan juga mampu memenuhi kewajiban baik jangka panjang maupun jangka pendek. Berdasarkan laporan laba rugi, perusahaan yang dijadikan sampel penelitian menunjukkan bahwa terdapat perusahaan mengalami rugi meskipun rasio hutang menunjukkan ketentuan yang aman yakni kurang dari 1 (satu). Seharusnya dengan rasio hutang kurang 1 (satu) menunjukkan bahwa perusahaan tidak banyak menanggung kewajiban yang tinggi. Tetapi hal ini tidak berpengaruh terhadap nilai perusahaan, artinya nilai perusahaan yang digambarkan oleh harga saham tidak dipengaruhi oleh penggunaan utang dalam membiayai aktivitas atau kegiatan perusahaan. Investor hanya memperhatikan bagaimana perusahaan menginvestasikan dananya dibandingkan dengan bagaimana perolehan dananya, ini dibuktikan dengan komposisi hutang lebih kecil dari modal saham. Artinya lebih banyak modal perusahaan yang berasal dari kepemilikan saham oleh investor sehingga sumber dana yang berasal dari utang menjadi lebih sedikit.

\section{Pembahasan Hasil Pengujian Hipotesis Keempat}

Pembahasan ini berkaitan dengan hasil pengujian terhadap hipotesis keempat yang menyatakan bahwa terdapat pengaruh keputusan investasi dan keputusan pendanaan yang signifikan secara simultan terhadap nilai perusahaan pada perusahaan manufaktur sektor barang konsumsi di Indonesia. Hasil penelitian menunjukkan bahwa variabel keputusan investasi dan keputusan pendanaan secara bersamasama berpengaruh signifikan terhadap nilai perusahaan. Keputusan Investasi adalah kegiatan menempatkan dana atau uang dengan tujuan untuk memelihara atau meningkatkan nilai serta mengharapkan hasil atau return positif atas kegiatan tersebut. Keputusan investasi menyangkut tentang keputusan pengalokasian dana baik dana yang berasal dari dalam perusahaan maupun dana yang berasal dari luar perusahaan pada berbagai bentuk investasi baik investasi jangka pendek maupun investasi jangka panjang. Keputusan pendanaan adalah keputusan mengenai pendanaan operasional perusahaan dengan menggunakan hutang, baik hutang jangka pendek maupun hutang jangka panjang. Keputusan pendanaan sangat bermanfaat bagi perusahaan dan bahkan mampu meningkatkan nilai perusahaan, karena perusahaan yang didanai oleh hutang akan menanggung beban bunga yang bisa mengurangi pendapatan kena pajak, sehingga menguntungkan bagi pemegang saham. Keputusan investasi dan keputusan pendanaan saling terkait dan keduanya harus dipertimbangkan dengan sebaik-baiknya oleh perusahaan dalam rangka peningkatan nilai perusahaan yang tercermin dalam harga saham.

\section{Pembahasan Hasil Pengujian Hipotesis Kelima}

Pembahasan ini berkaitan dengan hasil pengujian terhadap hipotesis kelima yang menyatakan bahwa terdapat hubungan kinerja keuangan yang signifikan terhadap nilai perusahaan pada perusahaan manufaktur sektor barang konsumsi di Indonesia. Hasil penelitian menunjukkan bahwa kinerja keuangan memiliki hubungan positif yang signifikan terhadap nilai perusahaan, artinya semakin tinggi kinerja keuangan maka semakin tinggi pula nilai perusahaan dan sebaliknya. Kinerja keuangan yang diwakili oleh return on equity, return on equity adalah kemampuan perusahaan menghasilkan laba dengan didasarkan pada ekuitas pemegang saham. Nilai perusahaan hanya ditentukan oleh kemampuan menghasilkan laba, ROE berkaitan dengan menghasilkan laba yang dihubungkan dengan besarnya ekuitas pemegang saham yang dimiliki perusahaan. Hal tersebut dibuktikan oleh hasil pengolahan data penelitian. Hasil pengolahan data menunjukkan bahwa rasio return on equity memiliki nilai di atas 1 (satu) artinya laba perusahaan banyak diperoleh dari modal saham.

\section{Pembahasan Hasil Pengujian Hipotesis Keenam}

Pembahasan ini berkaitan dengan hasil pengujian terhadap hipotesis keenam yang menyatakan bahwa terdapat hubungan keputusan investasi dan keputusan pendanaan yang signifikan secara parsial terhadap nilai perusahaan melalui kinerja keuangan pada perusahaan manufaktur sektor barang konsumsi di Indonesia. Hasil penelitian menunjukkan bahwa secara parsial keputusan investasi memiliki hubungan yang signifikan terhadap nilai perusahaan melalui kinerja keuangan. Sedangkan keputusan pendanaan tidak memiliki hubungan yang signifikan terhadap nilai perusahaan melalui kinerja keuangan. Keputusan investasi menyangkut tentang keputusan alokasi dana baik dana yang berasal dari dalam perusahaan maupun dana yang berasal dari luar perusahaan pada berbagai bentuk investasi. Sedangkan nilai perusahaan dipengaruhi oleh dua hal yaitu asset yang saat ini telah ditempatkan dan opsi untuk investasi di masa depan. Keputusan investasi yang dilakukan mengandung informasi yang berisi sinyal-sinyal akan prospek perusahaan di masa yang akan datang. Keputusan investasi berkaitan dengan return yang akan diterima. Oleh karenanya keputusan investasi memiliki hubungan yang sangat erat dengan nilai perusahaan.

Keputusan pendanaan adalah keputusan mengenai pendanaan operasional perusahaan dengan menggunakan hutang, baik hutang jangka pendek maupun hutang jangka panjang. Keputusan pendanaan sangat bermanfaat bagi perusahaan dan bahkan mampu meningkatkan nilai perusahaan, karena perusahaan yang didanai oleh hutang akan menanggung beban bunga yang bisa mengurangi pendapatan kena pajak, sehingga menguntungkan bagi pemegang saham. Tetapi sekali lagi keputusan pendanaan tidak 
memiliki hubungan dengan nilai perusahaan, hal tersebut disebabkan karena investor tidak memperdulikan bagaimana dana berasal, tetapi investor hanya melihat pada hasil akhir dan prospek perusahaan pada masa yang akan datang. Prospek itu hanya bisa terlihat dari keputuan investasi yang dilakukan oleh perusahaan.

\section{Pembahasan Hasil Pengujian Hipotesis Ketujuh}

Pembahasan ini berkaitan dengan hasil pengujian terhadap hipotesis ketujuh yang menyatakan bahwa terdapat hubungan keputusan investasi dan keputusan pendanaan yang signifikan secara simultan terhadap nilai perusahaan melalui kinerja keuangan pada perusahaan manufaktur sektor barang konsumsi di Indonesia. Hasil penelitian menunjukkan bahwa keputusan investasi dan keputusan pendanaan secara simultan memiliki hubungan dengan nilai perusahaan melalui kinerja keuangan. Hasil ini dibuktikan dengan nilai koefisien korelasi berganda $(R)$ sebesar 0,394 dengan signifikansi 0,005 yang berarti terbukti terdapat hubungan dengan kriteria yang cukup positif dan signifikan terhadap perubahan variabel kinerja keuangan pada perusahaan manufaktur sektor barang konsumsi di Indonesia. Selanjutnya nilai koefisien korelasi berganda $(R)$ sebesar 0,953 dengan signifikansi 0,000 yang berarti terbukti terdapat hubungan dengan kriteria yang sangat kuat positif dan signifikan terhadap perubahan variabel nilai perusahaan manufaktur sektor barang konsumsi di Indonesia. Ini berarti bahwa hubungan keputusan investasi dan keputusan pendanaan secara bersama-sama sangat kuat hubungannya baik dengan kinerja keuangan maupun nilai perusahaan. Apabila pendanaan didanai melalui hutang, peningkatan tersebut terjadi akibat dari efek tax deductible. Artinya, perusahaan yang memiliki hutang akan membayar bunga pinjaman yang dapat mengurangi penghasilan kena pajak, yang dapat memberi manfaat bagi pemegang saham. Selain itu, penggunaan dana eksternal akan menambah pendapatan perusahaan yang nantinya akan digunakan untuk kegiatan investasi yang menguntungkan bagi perusahaan (Fenandar, 2012:15). Investasi yang menguntungkan akan mampu meningkatkan kinerja keuangan dan akhirnya akan meningkatkan pula nilai perusahaan yang tercermin dalam harga saham.

\section{KESIMPULAN DAN SARAN \\ Kesimpulan}

Berdasarkan hasil penelitian dan pembahasan yang telah diuraikan di atas, maka dapat diambil beberapa kesimpulan sebagai berikut:

a. Hasil pengujian terhadap hipotesis pertama yang menyatakan bahwa terdapat pengaruh keputusan investasi dan keputusan pendanaan yang signifikan secara parsial terhadap kinerja keuangan pada perusahaan manufaktur sektor barang konsumsi di Indonesia. Hasil penelitian menunjukkan bahwa keputusan investasi berpengaruh signifikan terhadap kinerja keuangan, sedangkan keputusan pendanaan tidak berpengaruh signifikan terhadap kinerja keuangan.

b. Hasil pengujian terhadap hipotesis kedua yang menyatakan bahwa terdapat pengaruh keputusan investasi dan keputusan pendanaan yang signifikan secara simultan terhadap kinerja keuangan pada perusahaan manufaktur sektor barang konsumsi di Indonesia. Hasil penelitian menunjukkan bahwa keputusan investasi dan keputusan pendanaan secara simultan berpengaruh signifikan terhadap kinerja keuangan.

c. Hasil pengujian terhadap hipotesis ketiga yang menyatakan bahwa terdapat pengaruh keputusan investasi dan keputusan pendanaan yang signifikan secara parsial terhadap nilai perusahaan pada perusahaan manufaktur sektor barang konsumsi di Indonesia. Hasil penelitian menunjukkan bahwa keputusan investasi berpengaruh signifikan terhadap nilai perusahaan, sedangkan keputusan pendanaan tidak berpengaruh signifikan terhadap nilai perusahaan.

d. Hasil pengujian terhadap hipotesis keempat yang menyatakan bahwa terdapat pengaruh keputusan investasi dan keputusan pendanaan yang signifikan secara simultan terhadap nilai perusahaan pada perusahaan manufaktur sektor barang konsumsi di Indonesia. Hasil penelitian menunjukkan bahwa variabel keputusan investasi dan keputusan pendanaan secara bersama-sama berpengaruh signifikan terhadap nilai perusahaan.

e. Hasil pengujian terhadap hipotesis kelima yang menyatakan bahwa terdapat hubungan kinerja keuangan yang signifikan terhadap nilai perusahaan pada perusahaan manufaktur sektor barang konsumsi di Indonesia. Hasil penelitian menunjukkan bahwa kinerja keuangan memiliki hubungan positif yang signifikan terhadap nilai perusahaan

f. Hasil pengujian terhadap hipotesis keenam yang menyatakan bahwa terdapat hubungan keputusan investasi dan keputusan pendanaan yang signifikan secara parsial terhadap nilai perusahaan melalui kinerja keuangan pada perusahaan manufaktur sektor barang konsumsi di Indonesia. Hasil penelitian menunjukkan bahwa secara parsial keputusan investasi memiliki hubungan yang signifikan terhadap nilai perusahaan melalui kinerja keuangan. Sedangkan keputusan pendanaan tidak memiliki hubungan yang signifikan terhadap nilai perusahaan melalui kinerja keuangan.

g. hasil pengujian terhadap hipotesis ketujuh yang menyatakan bahwa terdapat hubungan keputusan investasi dan keputusan pendanaan yang signifikan secara simultan terhadap nilai perusahaan melalui kinerja keuangan pada perusahaan manufaktur sektor barang konsumsi di Indonesia. Hasil penelitian 
menunjukkan bahwa keputusan investasi dan keputusan pendanaan secara simultan memiliki hubungan dengan nilai perusahaan melalui kinerja keuangan.

\section{Saran}

Atas hasil penelitian dan pembahasan diatas, maka diberikan saran-saran kepada beberapa pihak sebagai berikut:

a. Bagi pihak manajemen perusahaan

Perusahaan harus tanggap terhadap beberapa faktor yang mampu meningkatkan nilai perusahaan terutama terkait dengan keputusan keuangan yang meliputi keputusan investasi dan keputusan pendanaan.

b. Bagi masyarakat calon investor

Calon investor harus tepat sasaran dalam memilih dan menempatkan dana yang dimilikinya, karena hal tersebut akan berimbas terhadap return yang akan diterima oleh masyarakat atau calon investor.

c. Bagi investor

Investor harus selalu melakukan kontrol terhadap perkembangan perusahaan terutama yang menyangkut keputusan investasi dan keputusan pendanaan yang dilakukan perusahaan. Kedua keputusan keuangan tersebut harus diperhatikan betul oleh investor yang nantinya akan berimbas terhadap aktivitas penjualan. Investor harus terus memantau nilai perusahaan yang tercermin dalam harga saham, agar investor mampu memperhitungkan kapan kondisi aman bagi mereka.

d. Bagi peneliti selanjutnya

Peneliti selanjutnya disarankan untuk meneliti variabel lain yang mampu meningkatkan nilai perusahaan melalui kinerja keuangan, juga jenis dan jumlah perusahaan lainnya yang akan dijadikan sampel penelitian agar hasil penelitian menjadi tidak bias dan tepat.

\section{DAFTAR PUSTAKA}

Halim, Abdul. 2007. Manajemen Keuangan Bisnis. Bogor. Ghalia Indonesia.

Sartono, Agus. 2001. Manajemen Keuangan Teori dan Aplikasi. Yogyakarta. BPEF.

Mahendra DJ, Alfredo. 2011. Pengaruh Kinerja Keuangan Terhadap Nilai Perusahaan (Kebijakan Dividen sebagai Variabel Moderating) Pada Perusahaan Manufaktur di Bursa Efek Indonesia. Denpasar. Program Pascasarjana Universitas Udayana.

Andini, dan Nadia Putri. 2015. Pengaruh Keputusan Investasi, Keputusan Pendanaan, dan Kebijakan Dividen Terhadap Nilai Perusahaan. Widyatama Repository.

Afzal, Arie, dan Abdul Rohman. 2012. Pengaruh Keputusan Investasi, Keputusan Pendanaan, dan Kebijakan Dividen Terhadap Nilai Perusahaan. Diponegoro Journal of Accounting. 1(2). Halaman 09.

Santoso, Cindy Leony. 2017. Hubungan Keputusan Investasi, Keputusan Pendanaan, Kebijakan Dividen, Tingkat Inflasi dan Suku Bunga Dengan Nilai Perusahaan. Universitas Sanata Dharma. Yogyakarta.

Harmono. 2016. Manajemen Keuangan Berbasis Balanced Scorecard Pendekatan Teori, Kasus, dan Riset Bisnis. Jakarta. Bumi Aksara.

Hasnawati, Sri. 2005. Implikasi Keputusan Investasi, Pendanaan, dan Dividen terhadap Nilai Perusahaan Publik di BEJ. Usahawan No. 09 Tahun XXXIV, September 2005.

Fahmi, Irham. 2014. Manajemen Keuangan Perusahaan dan Pasar Modal. Edisi Pertama. Jakarta. Mitra Wacana Media.

Horne, James C. Van, dan John M. Wachowicz. JR. 2007. Fundamental of Financial Management Prinsipprinsip Manajemen Keuangan. Buku 2 Edisi 12. Jakarta. Salemba Empat.

Jubaedah, dan Jenji Gunaedi Argo. 2012. The Influence Of Investment Decision, Capital Decision And Financial Performance On The Company Values In Manufacture Company Registered In Indonesian Stock Market. JMK, VOL. 17, NO. 1, MARET 2015, 65-75 DOI: 10.9744/jmk.17.1.65-75 ISSN 1411-1438 print / ISSN 2338-8234 online.

Keown, Arthur J., John D. Martin, J. William Petty dan David F. Scott, JR. 2010. Manajemen Keuangan: Prinsip dan Penerapan Jilid 2. Jakarta: Indeks.

Khafa, Lais. 2015. Pengaruh CSR, Ukuran Perusahaan, Leverage, dan Keputusan Investasi Pada Kinerja Keuangan Perusahaan dan Nilai Perusahaan. Universitas Diponegoro. Semarang.

Modigliani, F., dan Miller, H. 1963. Corporate income taxes and the cost of capital: a correction. American Economic Review. Vol. 53: 443-453.

Munawir. 2010. Analisa Laporan Keuangan. Edisi 4. Yogyakarta. Liberty.

Myers, S. 1977. Determinants Of Corporate Borrowing. Journal of Financial Economics. 5: 141-175.

Ningrum, Nurika Samti Febriana. 2006. Analisis Pengaruh Keputusan Investasi, Keputusan Pendanaan, dan Kebijakan Dividen Terhadap Nilai Perusahaan Manufaktur di BEJ. Tesis: Program Magister Manajemen STIE STIKUBANK Semarang.

Hardiningsih, Pancawati. 2009. Determinan Nilai Perusahaan. Universitas STIKUBANK Semarang JAI Vol.5, No.2, Juli 2009 : 231-250.

Setiani, Rury. 2014. Pengaruh Keputusan Investasi, Keputusan Pendanaan, dan Tingkat Suku Bunga Terhadap Nilai Perusahaan Pada Perusahaan Otomatif Yang Terdaftar di Bursa Efek Indonesia. 
Alumni Fakultas Ekonomi UNP.

Achmad, Safitri Lia, dan Lailatul Amanah. 2014. Pengaruh Keputusan Investasi, Keputusan Pendanaan, Kebijakan Dividen Dan Kinerja Keuangan Terhadap Nilai Perusahaan. Jurnal Ilmu \& Riset Akuntansi Vol. 3 No. 9 (2014). 